CESIS Electronic Working Paper Series

Paper No. 319

\title{
T New firms and labor market entrants: Is there a wage penalty for employment in new firms?
}

\author{
Kristina Nyström \\ Gulzat Zhetibaeva Elvung
}

June, 2013 


\title{
New firms and labor market entrants: Is
}

\section{there a wage penalty for employment in new firms?}

\author{
Kristina Nyström and Gulzat Zhetibaeva Elvung \\ Department of Industrial Economics and Management, The Royal Institute of Technology, \\ Stockholm
}

\begin{abstract}
:
In this paper, we explore the role of new firms as an entry point to the labor market. Because the vast majority of new firms are short-lived, it is a risky decision to accept employment in a new venture. It can be argued that individuals with little (or no) labor market experience are more willing to accept the high risks associated with employment in new firms. Hence, new firms may work as an entry point to the labor market. Nevertheless, some research concludes that one disadvantage of employment in a new firm is that new firms pay less (Shane, 2009). However, this empirical conclusion is primarily based on literature on the wage penalty of small firms. In this paper, we study whether the wage penalty of employment in a new firm persists if we focus solely on labor market entrants. In the empirical analysis, we employ an employer-employee matched dataset that covers the Swedish population during the period from 1998-2008. We use the Propensity Score Matching (PSM) method to study the wage differences between labor market entrants employed in new and incumbent firms. We find an average wage penalty of 2.9 percent for labor market entrants employed in new firms over the studied period.
\end{abstract}

Keywords: new firms, labor market entrants, wage penalty, propensity score matching, average treatment effect.

JEL classification: M13, J21, J31, C21 


\section{Introduction}

According to previous empirical research, accepting employment in a newly established business is very risky and less attractive in pecuniary terms. First, there is a high probability of job destruction because the vast majority of jobs in new firms are destroyed within five years (e.g., Geroski, 1995, Shane 2008). Second, new firms tend to provide worse conditions in terms of lower wage and fringe benefits than incumbent firms (Shane, 2009) ${ }^{1}$. Given these circumstances, it is reasonable to ask why anyone would accept a job offer in a new entrepreneurial venture. Theoretically, a new firm should have to pay more to compensate for the risk of employment in a firm with a higher probability of failure. It can be argued that individuals with less (or no) experience in the labor market are more willing to accept the high risks associated with employment in new firms. Hence, new firms may work as an entry point to the labor market for employees seeking their first job.

Recent studies have explored the role of new firms in relation to labor mobility. Nyström (2011) shows that the share of employees from outside the labor market was higher for new firms compared with incumbent firms. Furthermore, new firms employ a higher share of immigrants. However, Nyström (2011) does not distinguish between different types of "outsiders". Hence, it would be interesting to focus on the role of new firms for employees who face a similar situation. In this paper, we focus on the role of new firms for labor market entrants, i.e., individuals who obtain their first job. In particular, we focus on the alleged wage penalty associated with employment in new firms. Is there a wage penalty of employment in a new firm if we focus solely on labor market entrants? In this paper, we use Swedish matched employer-employee data and the Propensity Score Matching (PSM) method to study the wage differences between labor market entrants employed in new and incumbent firms during the period from 1998-2008. Previous studies (see, e.g., Heyman, 2007 for a study based on Swedish data) that investigate wage differences between new firms and incumbent firms do not explicitly focus on labor market status, such as whether employees are recruited from outside the labor market. Furthermore, Heyman (2007) finds that the wage penalty varies for the three years included in his study. In this study, we cover the period from 1998-2008, which enables us to investigate the variation across years. Our estimates of the wage penalty range between 0.6 and 4.9 percent. The average wage penalty over the period $1998-2008$ is 2.9 percent.

The paper is structured as follows: Section two provides the theoretical framework and discusses previous empirical findings. Section three presents the data and descriptive statistics. Section four provides the methodology and empirical approach regarding the wage penalty associated with employment in a new firm for labor market entrants. The results of our estimates are presented and discussed in section five. Finally, section six concludes and provides suggestions for further studies.

\section{Labor market entry and the role of new firms - theory and previous studies}

Previous studies on the wage penalty of employment in entrepreneurial firms focus on the relationship between firm size and wages. Wagner (1997) provides a literature review of a number of studies and concludes that small firms offer worse jobs than large firms because

\footnotetext{
${ }^{1}$ However, as noted by van Praag and Versloot (2007), there may be other non-pecuniary benefits associated with entrepreneurship. We may hypothesize, for example, that it may be attractive and interesting to participate as an employee in a new venture in developing a new business idea and building a new company.
} 
wages are lower, fringe benefits are lower, job security is lower and opportunities for skill enhancement are worse. The finding of lower wages in small firms is also confirmed by Troske (1999), Bayard and Troske (1999) and Waddoups (2007). Millimet (2005) goes further with respect to unraveling the wage penalty of employment in a small firm. He finds that approximately 20 percent of the difference in observed wages across large and small firms is attributable to differences in observable job search skills.

Many economists have evaluated the link between firm size and wages by empirically controlling for various combinations of individual characteristics (race, gender, marital status, age, educational attainment, tenure, etc.), firm characteristics (industry, occupation, position, union, etc.) and labor market conditions (industry and region). In general, many studies find a positive relationship between employer size and wages; however, the observable characteristics do not fully account for the size-wage premium. As Millimet (2005) argues, there is a sizeable residual that remains unexplained in such empirical evaluations, and the reasons underlying the size-wage premium are not clear. Brown and Medoff (1989) assess several hypotheses for wage differentials and conclude that the size-wage relationship is sizeable and omnipresent, and it cannot be fully explained by observable characteristics of labor quality. Similarly, Troske (1999) uses linked employer-employee data for a large sample of U.S. manufacturing workers and establishments to examine the size-wage premium and concludes that in the end, there remains a large, significant and unexplained premium paid to workers of large employers.

The positive size-wage relationship indicates that on average, large firms pay higher wages while small firms pay lower wages. Shane (2009) claims that the jobs created by start-ups are worse than jobs in existing companies in terms of payment and fringe benefits. However, Shane (2009) refers to Wagner (1997), who reviews empirical studies on job quality and firm size rather than firm age. Because larger firms are generally older firms and younger firms tend to be smaller, it is reasonable to ask whether small firms are also new firms. "Is it possible that the size-wage premium is really a relationship between employer age and wages?" (Brown and Medoff, 1989, pp. 1056) Theoretically, the age of the firm is an important firm characteristic in wage determination, as summarized by Brown and Medoff (2003).

Although the question on the firm age-wage link has been an object of interest for both researchers and policy makers for many years, only a few studies have looked at this relationship. One of the most influential studies on the firm age-wage relationship was carried out by Brown and Medoff (2003). They use data from special supplements to the Survey Research Center's monthly Survey of Consumers and find that firms that have been in business longer pay higher wages. However, they claim that the relationship is not monotonic, with wages falling and then rising with years in business. Another study by Heyman (2007) uses a matched employer-employee dataset for Sweden. The results indicate that the inclusion of firm age does not affect the impact of firm size on wages. In sum, a firm's age does not fully account for wage differentials across individuals and firms.

As the theory of human capital suggests, wage differentials are influenced by differentials in individual productivity, which are themselves influenced by investments in education or training. According to Troske (1999), one possible explanation for large employers paying higher wages is that large employers hire better workers in the sense that both large employers and their employees are more likely to invest in firm-specific human capital. Similarly, Gerlach and Hübler (1998) find that the average levels of employees' qualifications vary considerably between small and large firms, and larger firms attract more qualified workers, although average 
wages increase with firm size after controlling for various individual and firm characteristics. There is some indication that the composition of employment in terms of quality differs across firms, with larger firms having a higher proportion of qualified workers than smaller firms. These findings show that individuals with greater abilities and skills are selected disproportionally into larger, and on average older, firms.

On the other hand, in contrast to larger firms that are in general older, new firms that are usually equated with smaller firms are found to be more important for a certain group of employees. For instance, Nyström (2011) uses a unique matched firm-employees dataset and finds that the share of immigrants, recently graduated employees and people entering the labor market is higher in new firms. The author concludes that new firms might play a more important role for outsiders in the labor market. Similarly, Ouimet and Zarutskie (2011), controlling for firm size, industry, geography and time, provide evidence that young firms disproportionately hire young employees. Another study by Brixy et al. (2007) uses a linked employer-employee dataset for Germany to analyze wage setting in newly founded and other firms. They find that on average, wages in newly founded establishments are 8 percent lower than in similar incumbent firms. Although they have information on individual characteristics such as employee sex, age and qualifications for four levels (part-time, fixed-term, high-skilled and low-skilled employees), they use the aggregate data at the establishment level.

\section{Wage setting in the welfare state}

When discussing wage setting in entrepreneurial firms, the institutional setting needs to be considered. In fact, the particularities of the institutional setting and the changes in terms of wage negotiations experienced in the last decades makes Sweden a particularly interesting case to study. The Swedish welfare state model is characterized by high rates of unionization and collective bargaining. To what extent does the system of collective bargaining compress wages and limit the wage span available for potential labor market entrants to negotiate wages? Since the severe economic crisis in the early 1990s, wage formation in Sweden has become more decentralized. Minimum wages are still negotiated at the central level, but unions and employers negotiate wage levels above minimum wages at the local level (Fredriksson and Topel, 2010). The decentralization of wage negotiations contributes to the increase in wage dispersion, which has increased since the 1990s (Freeman, Swedenborg and Topel (2010). Furthermore, it should be mentioned that almost 60 percent of Swedish firms do not have any collective bargaining agreement. The share of firms without collective bargaining agreements is even higher in small firms and in new and fast-growing industries. Among companies with less than five employees, the share of firms without collective bargaining agreements is almost 70 percent (Företagarna, 2011). In conclusion, there are still great possibilities for new firm employers to use wage policy to attract competent employees to their ventures.

\section{Data description}

The data used in this paper are derived from a unique matched employee-firm dataset provided by Statistics Sweden. For each individual in the dataset, information on age, gender, immigration status, and education is available. The database consists of extremely detailed information for all employees in Sweden. We use data for the entire private sector for the period from 1998-2008, 
where 2008 is the last year of data available to us. The unit of observation is a labor market entrant, which we define in reference to the "insider-outsider" theory (Lindbeck and Snower, 2002). According to this theory, "insiders" are employees who enjoy protected employment opportunities due to seniority, while "outsiders" are either unemployed or obtain work only temporarily. When an outsider is employed, he/she becomes a labor market entrant with the possibility of becoming an insider if he/she remains in the firm for a sufficient period. In this paper, we define a labor market entrant as an individual who obtains his/her first job and hence gains an opportunity to become an insider.

To select entrants from the dataset, we impose a number of conditions. First, we select all individuals who became employed for the first time in the observed year. Moreover, we restrict these individuals to only those who obtained full-time employment in the private sector. Following Skans et al. (2006), we consider a person to be employed full time if the wage exceeds a minimum wage, which is defined as 75 percent of the mean wage of janitors employed by local municipalities. We do not have occupation variables for some years, so we take 50 percent of the average wage of all employees as the minimum wage because this value is close to the minimum wage defined by Skans et al. (2006) ${ }^{2}$. This index is calculated on an annual basis. Furthermore, we restrict individuals to those who are at or below 30 years old. We introduce three definitions of new firms. In our analysis, the models corresponding to the three definitions of new firms are denoted as Model I, Model II and Model III, where new firms are defined as newly established firms i.e. less than one year old (Model I), firms that are up to three years old (Model II), and firms that are up to five years old (Model III). Incumbent firms in each model are firms not defined as new firms.

Table 1 presents the average wages in SEK of labor market entrants employed in new and incumbent firms. We can observe that for all years and for the three definitions of new and recent firms, the average wage is lower in the newly established firms.

\section{Table 1 about here}

\section{Methodology and empirical approach}

\section{Analytical framework}

The question addressed in this paper is to estimate the wage penalty on labor market entrants for employment in a new firm. An individual is not assigned to a new firm randomly but instead obtains employment based on many factors such as abilities, skills, etc., which might also have an effect on the outcome of the assignment. Propensity Score Matching (PSM) can address the potential sample selection problem; it is widely used to measure effects of "treatments" using observational data. Following Rosenbaum and Rubin (1983), we define "treatment" ( $T$ ) in our model as the assignment of an individual, a labor market entrant, to a newly established firms or recent entrants, and we apply the PSM method to estimate the "treatment effect" of the selection of individuals into new firms or recent entrants on their wages. We consider three cases, Models I, II and III, described in the previous section. The main assumption imposed here is that individuals selected into treatment and non-treatment groups have potential outcomes in both

\footnotetext{
${ }^{2}$ For 2008 , the minimum wage in our analysis is SEK 142,806 , while the minimum wage calculated according to Skans et al. (2006) is SEK 142,250.
} 
states. The outcome variable is the natural logarithm of the individual's annual wage. The "treatment effect" is the difference between the annual wages of an individual in two states: 1) the individual is employed by a new firm, and 2) the individual is employed by an incumbent firm. To estimate this effect, we employ the PSM method, following Caliendo and Kopeinig (2008), and we describe the parameter of interest as follows:

For each individual $i$ we consider a binary treatment $T_{i}$. Let there be $N$ individuals (labor market entrants). In this case, the treatment indicator $T_{i}$ equals one if an individual $i$ receives treatment and zero otherwise. We define $T_{i}=1$ if an individual is employed in a new firm and $T_{i}=0$ otherwise. The outcome variable is defined as $Y_{i}\left(T_{i}\right)$ for each individual $i$, where $i=1,2, \ldots, N$. We are interested in finding the average treatment effect on the treated (ATT), $\tau_{A T T}$, defined as the difference between the expected outcome values with and without treatment for those who actually participated in treatment.

$$
\tau_{A T T}=E(\tau \mid T=1)=E[Y(1) \mid T=1]-E[Y(0) \mid T=1]
$$

Because we observe for each individual $i$ either $E\left[Y_{i}(0) \mid T_{i}=0\right]$ or $E\left[Y_{i}(1) \mid T_{i}=1\right]$, we may have a selection bias as in the left hand side of the equation (2):

$$
E[Y(1) \mid T=1]-E[Y(0) \mid T=0]=\tau_{A T T}+E[Y(0) \mid T=1]-E[Y(0) \mid T=0]
$$

The true parameter $\tau_{A T T}$ is only identified if Bias $=0$. Because we do not have experimental data where assignment to treatment is random, we need to impose some identifying assumptions to minimize the bias.

\section{Propensity Score Matching}

We approach this problem by employing a matching method using a balancing score, Propensity Score $P(X)$, as suggested by Rosenbaum and Rubin (1983). The Propensity Score is defined as the probability for an individual to participate in a treatment given his/her set of observable characteristics $X$. The basic idea of this approach is that we infer the characteristics of an individual $i$ selected into a new firm by matching them, by their Propensity Score, with observed individuals selected into an incumbent firm. Two assumptions need to be satisfied to apply this method: unconfoundedness and common support or overlap condition. The first assumption implies that an observation with an identical Propensity Score with the opposite treatment assignment represents the unobserved counterfactual. The second assumption implies that individuals with the same observed characteristics have a positive probability of being both participants and nonparticipants. Assuming that both of the identifying assumptions hold, we define the Propensity Score Matching estimator for ATT $\left(\tau_{A T T}^{P S M}\right)$ as the mean difference in the logarithm of annual wages over the common support, weighted by the Propensity Score.

$$
\tau_{A T T}^{P S M}=E[P(X) \mid T=1]\{E[Y(1) \mid T=1, P(X)]-E[Y(0) \mid T=0, P(X)]\}
$$

To implement the PSM method in our analyses, we follow the guidance summarized by Caliendo and Kopeinig (2008). First, we estimate the Propensity Score, or the individual probability of being selected into a new firm given the observed covariates of individual $X$. For binary treatment, as in our case, both probit and logit models should yield similar results. In this paper, we use the logit model to estimate Propensity Scores. There are a number of methods to match treatment and control groups (not treated groups) based on the Propensity Score. Selection of matching algorithms is subject to trade-offs in terms of bias and efficiency. However, 
asymptotically all PSM estimators should yield the same results (Smith, 2000). In this paper, we use several matching algorithms: nearest neighbor matching (NNM) without replacement, caliper with tolerance levels $0.001,0.01$ and 0.02 , NNM with replacement and NNM with 2 neighbors ${ }^{3}$. To check the 'balance requirement', whether the matching procedure is able to balance the distribution of the relevant variables in both the control and treatment groups, we use the t-test for differences in covariate means for both groups. To estimate standard errors for the estimates of the ATT, we use the bootstrapping method (Lechner, 2002). Matching estimators are not robust against hidden biases, unobserved variables that affect assignment into the treatment and the outcome variable simultaneously (Rosenbaum, 2002). We perform sensitivity analyses using Rosenbaum bounds.

\section{Selection of covariates}

Unconfoundedess or conditional independence implies that one should choose explanatory variables that have impacts on both the outcome variable and the treatment assignment. ${ }^{4}$ In our model, such a set of variables includes skills, ability measures, and demographic and geographic variables, as displayed in Table 2. The variables are chosen based on their economic significance, and they may affect wage differentials and selection into new firms. We use the following set of explanatory variables: (i) basic individual characteristics including Age (age of employee), Age squared, Gender (female), Immigrant ${ }^{5}$ (immigrant background), Europe and North America (born in a European country or in North America), Non-Europe/North America (born in countries other than Europe or North America), using born in Sweden as a reference group; (ii) education variables including Secondary education (the highest attained education is secondary education or less than two or three years of post-secondary education), Tertiary education (the highest attained education is post-secondary education for two or three years or longer or graduate), using individuals with education less than or equal to compulsory schooling as the reference group, and $G P A^{6}$ (GPA scores, 1-20 points), educational field defined as Pedagogical and arts (pedagogical or humanities and arts education), Social (social sciences, law, commerce, administration) and Technical (science, mathematics, computers, technology and manufacturing), with a reference group of employees with general and other education ${ }^{7}$; (iii) parental education including Father's secondary education (father's highest attained education is secondary education for 3 years or post-secondary education for less than 3 years), Father's tertiary education (father's highest attained education is post-secondary education for 3 years or longer or graduate), Mother's secondary education (mother's highest attained education is secondary education for 3 years or post-secondary education for less than 3 years), Mother's tertiary education (mother's highest attained education is post-secondary education for 3 years or longer or graduate), with the reference group a parent with highest education that is less than or equal to compulsory schooling; and (iv) residential municipality variables Stockholm,

\footnotetext{
${ }^{3}$ See Caliendo and Kopeinig (2008) for a detailed summary of the matching methods.

${ }^{4}$ Note that this assumption excludes the possibility of including firm characteristics associated with employment in new or incumbent firms as explanatory variables.

${ }^{5}$ We define a person with an immigrant background as a person who is foreign-born or is domestically born and has two foreign-born parents.

${ }^{6}$ Grade Point Average.

${ }^{7}$ Educational field includes secondary, post-secondary and graduate education; this variable is not strongly correlated with the other education variables.
} 
Gothenburg and Malmo, defined by the local labor markets ${ }^{8}$ Stockholm, Gothenburg and Malmo, respectively.

In human capital theory, education is the source of an accumulation of competences that have impacts on wages. Education is used in any wage equation, as proposed by Mincer (1974). Parental education has also proven to be important for children's educational attainment and wage determination (Taubman, 1989; Chevalier et al., 2005; Davis-Kean, 2005). Many studies find that gender and ethnicity affect wage differentials (Blau and Kahn, 2001) as well as differences in employment opportunities (Darity and Mason, 1998; Altoniji and Blank, 1999). Thus, the gender and immigrant background variables may affect both selection into new or incumbent firms and the outcomes of the selection. Finally, because labor market agglomeration affects wages (Wheaton and Lewis, 2002), we also choose residential municipality variables.

Table 2 displays descriptive statistics for the variables involved in the estimations and differentiates between the treatment and control observations for Models I, II and III for 2008. Additionally, p-values from tests for significant differences in means are reported. The table shows that there are statistically significant differences with respect to individual characteristics such as immigrant background, place of birth (Non-Europe/North America), education variables, father's education and geographic location. For example, individuals in new or recently established firms are more likely to have lower GPA scores, to reside in Stockholm or Malmo, and to have an immigrant background and are less likely to have tertiary education, compared with labor market entrants in incumbent firms.

\section{Table 2 about here}

\section{The wage penalty on labor market entrants for employment in a young firm}

In this section, we present the results of the PSM estimates of the wage penalty on labor market entrants employed in a new firm. As previously mentioned, our data covers the period from 1998-2008. However, reporting the complete estimation results (descriptive statistics, logitestimations, and different matching algorithms) is superfluous. ${ }^{9}$ Hence, we choose to report the results for the last year available (2008). For the estimates of the average treatment effects (ATT), we report the results using NNM without replacement.

\section{Preliminary analyses}

The estimation results for the three models through a binary logit model that is used to calculate the Propensity Score, $P(X)$, and the probability of an individual's selection into a newly established (recent) firm, are displayed in Table 3. They show that an individual's immigrant background, GPA score and technical education field have a significant impact on selection into new firms for all three models. In the first model, the age variable is significant and has an inverse U-shaped effect on the selection. The probability of being employed in a new firm increases for women and individuals from an immigrant background, and the probability decreases for individuals with a technical education. Moreover, the higher the GPA score, the lower the probability is of being selected by a new firm. The same significance pattern is not

\footnotetext{
${ }^{8}$ Sweden consists of 289 municipalities and 72 local labor market regions. Local labor market regions are defined based on commuting patterns between municipalities.

${ }^{9}$ The estimates for each individual year are available from the authors upon request.
} 
observed for the other two models, although the signs remain consistent. It should be noted that the explanatory power of the logit model is relatively low. Hence, there are unobserved individual characteristics that contribute to the selection of labor market entrants into new and incumbent firms.

\section{Table 3 about here}

\section{ATT estimates}

As we discussed in the methodology section, we use the t-test for differences in covariate means for both groups to check the 'balance requirement'. The t-tests after matching show no significant differences between the treatment and control groups in all three models; thus, we achieve the balancing requirement for the models. Table 4 displays the ATT estimation results for all three models using various matching algorithms for 2008. The table shows that the negative treatment effect ranges from 3.4 percent to 4.1 percent for Model I and from 2.7 percent to 3.4 percent for Model II. For Model III, the ATT estimates vary between 3.8 percent and 4.1 percent. Using 100 times bootstrapping, we also report bootstrapped standard errors for the estimated average treatment effect for the treated. In sum, the effect of being employed in a new firm compared with an incumbent firm leads to a reduction of annual wages by more than 3 percent (Model I).

\section{Table 4 about here}

Table 5 reports the ATT estimates using the NNM without replacement algorithm. For Model I, the ATT estimates vary between 1.7 percent and 4.1 percent, and Model II varies between 0.6 percent and 4.3 percent. In Model III, the estimates vary between 0.6 percent and 4.9 percent. However, the average wage penalty for all the models is 2.9 percent over the period. There are no clear patterns of tendencies in terms of increases or decreases in the wage penalty over time. Because there are important differences in the research methodology, it is difficult to accurately compare our findings with estimates of the wage penalty of employment from previous research. However, our focus on a group of individuals with similar positions in the labor market, i.e., labor market entrants, generally reveals a smaller wage penalty compared with, e.g., Brixy et al. (2007), who report a wage penalty for employees in new firms of 8 percent.

\section{Table 5 about here}

\section{Robustness checks}

We also perform sensitivity analyses to test the robustness of our results using Rosenbaum's (2002) bounding approach and to determine how strongly an unmeasured variable influences the matching estimates. For $2008^{10}$, the results for all three models show that as $\Gamma$, the Rosenbaum bounds estimate of the magnitude of selection bias on the unobserved covariate, approaches the value between 1.2 and 1.3, a 95 percent confidence interval contains zero so that the matching estimate becomes insignificant, corresponding to the given magnitude of hidden bias. Following

\footnotetext{
${ }^{10}$ The estimates for each individual year are similar and available from the authors upon request.
} 
Becker and Caliendo (2007), we note that these results are worst-case scenarios. A critical value of $\Gamma=1.2$ does not mean that unobserved heterogeneity exists and that there is no effect of selection into a new firm on the outcome variable, log of wages. This result only states that the confidence interval for the treatment effect would include zero if an unobserved variable caused the odds ratio of the treatment assignment to differ between the treatment and comparison groups by 1.2. Hence, Rosenbaum's test indicate that we cannot state whether the conditional independence assumption holds or does not hold for the given setting.

As we see in Table 3, the number of observations differs from Table 2 due to missing values. These missing values are mostly present in the parental education and GPA variables. To check our estimation results for robustness, we perform a PSM analysis using only covariates without these variables. By using NNM without replacement for the period from 1998-2008, we find that the average treatment effect on wages is negative and approximately 3.7 percent, which is, very close to the results we obtained with all covariates.

\section{Conclusions and suggestions for future research}

In this paper, we explore the role of new firms for labor market entrants. In particular, we examine the wage penalty on labor market entrants of employment in a new firm using the Propensity Score Matching method (PSM). There are several factors, which influence the wage an employee in a new firm is willing to accept. One the one hand a new firm may have to pay more to compensate for the risk of being employed in a firm, which has a higher probability of failure. On the other hand many newly established firms face financial constraints which may influence the wage that they are able to offer. Furthermore, there may be several benefits associated with employment in a newly established firm, which is not included in the current wage. For instance, new entrepreneurial firms may offer possibilities to participate in profitsharing schemes in order to enhance motivation to accept the employment. In addition, it may, for example, be that employees in a new firm you have to learn a variety of tasks which can advance their future value on the labor market.

We find that there is a wage penalty associated with employment in new firms for labor market entrants. However, the penalty is rather small. The estimated wage penalty varies across years between 0.6 percent to 4.9 percent. We do not observe any patterns in terms of increases or decreases in the wage penalty over time. Hence, the increased wage dispersion observed in the Swedish welfare state after the economic crisis in the 1990s seems not to have influenced the wage penalty. For 1998-2008, the average wage penalty is 2.9 percent for all three definitions of new firms used in the paper. Hence, our estimates of the wage penalty are smaller compared with many other studies that include more heterogeneous groups of employees, in terms of position in the labor market.

Our analysis on wage differentials between employees in new firms, recent entrants and incumbent firms focuses on a specific type of labor mobility - labor market entrants. For future studies, it would be interesting to also focus on other types of labor mobility such as job switchers or employees affected by firm closures. Furthermore, our study indicates that it would be interesting to further explore which individual characteristics determine selection into employment with new firms. Further exploration of the role of new firms for labor market entrants may also include following labor market entrants in new firms over time. Is employment in new firms a persistent or temporary employment? Finally, it would be interesting to conduct a qualitative study of the rationales and motivations for accepting an employment in a new firm. 


\section{References}

Altonji, J., and Blank, R. (1999) "Race and gender in the labor market" in Ashenfelter, O., and Card, D. (eds.), Handbook of Labor Economics, vol. 3C., chap. 48, pp. 3143-3259, Amsterdam: Elsevier science/North-Holland.

Bayard, K. and Troske, K. R. (1999) "Examining the Employer-Size Wage Premium in the Manufacturing, Retail Trade, and Service Industries Using Employer-Employee Matched Data", American Economic Review, 89(2): 99-103.

Becker, S. O. and Caliendo, M. (2007) "Sensitivity analyses for average treatment effects", The Stata Journal, 7(1): 71-83.

Blau, F. D. and Kahn, L. M. (2001) "Gender differences in pay”, NBER working paper series, Working Paper 7732.

Brixy, U., Kohaut, S. and Schnabel, C. (2007) "Do Newly Founded Firms Pay Lower Wages? First Evidence from Germany”, Small Business Economics, 29:161-171.

Brown, C. and Medoff, J. (1989) "The employee size-wage effect", Journal of Political Economy, 97 (5): 1027-1059.

Brown, C. and Medoff, J. L. (2003) "Firm Age and Wages", Journal of Labor Economics, 21 (3): 677-697.

Caliendo, M. and Kopeinig, S. (2008) "Some practical guidance for the implementation of propensity score matching", Journal of Economic Surveys, 22(1): 31-72.

Chevalier, A., Harmon, C., O’Sullivan, V., and Walker, I. (2005) “The impact of parental income and education on the schooling of their children", The institute for fiscal studies, Working Paper 5.

Darity Jr. and Mason, P. L. (1998) "Evidence on Discrimination in Employment: Codes of Color, Codes of Gender", The Journal of Economic Perspectives, 12( 2): 63-90.

Davis-Kean, P. E. (2005): "Influence of Parent Education and Family Income on Child Achievement: The Indirect Role of Parental Expectations and the Home", Environment Journal of Family Psychology, 19(2): 294-304.

Företagarna (2011) "Småföretagen och kollektivavtalen- Det måste bli frivilligt att teckna kollektivavtal" (Small firms and collective agreements) Report, Swedish Federation of Business Owners, Stockholm.

Fredriksson, P., and Topel, R. (2010) "Wage Determination and Employment in Sweden Since the Early 1990s: Wage Formation in a New Setting", in Freeman, R. B., Swedenborg, B., and Topel, R. (eds.), Reforming the Welfare State: Recovery and Beyond in Sweden, chap. 3, pp. 83 - 126, The University of Chicago Press.

Freeman, R. B., Swedenborg, B. and Topel, R. H. (2010) "Introduction", in Freeman, R. B., Swedenborg, B., and Topel, R. (eds.), Reforming the Welfare State: Recovery and Beyond in Sweden, pp. 1-23, The University of Chicago Press.

Gerlach, K. and Hübler, O. (1998) "Firm Size and Wages in Germany - Trends and Impacts of Mobility", Empirica, 25: 245-261. 
Geroski, P.A. (1995), What Do We Know About Entry?, International Journal of Industrial Organization, 13: 421-440.

Greene, W. H. (2003). Econometric analysis. Prentice Hall, New Jersey

Guo, S. And Fraser, M. W. (2010): "Propensity score analyses. Statistical methods and applications", SAGE Publications, Inc.

Heyman, F. (2007) "Firm Size or Firm Age? The Effect on Wages Using Matched Employer-Employee Data”, Labour, 21 (2): 237-263.

Kaiser, U. and Malchow-Møller, N. (2011): "Is self-employment really a bad experience? The effects of previous self-employment on subsequent wage-employment wages", Journal of Business Venturing, 26: 572-588.

Lechner, M. (2002) Some practical issues in the evaluation of heterogeneous labour market programmes by matching methods. Journal of the Royal Statistical Society, A 165: 5982.

Lindbeck, A. and Snower, D. (2001): "Insiders versus Outsiders", Journal of Economic Perspectives, 15(1): 165-188.

Millimet, D. L. (2005) "Job search skills, employer size and wages", Applied Economics Letters, 12 (2): 95-100.

Mincer, J., (1974). Schooling, Experience, and Earnings. Columbia University Press, New York.

Nyström, K. (2007). Patterns and determinants of entry and exit in industrial sectors in Sweden. Journal of International Entrepreneurship, 5(3-4):85-110.

Nyström, K. (2011) “Labor mobility and entrepreneurship: Who do new firms employ?", CESIS Electronic Working Paper Series, Working Paper 250.

Ouimet, P. and Zarutskie, R. (2011) "Who Works for Startups? The Relation between Firm Age, Employee Age, and Growth", US Census Bureau Center for Economic Studies, Working Paper CES-WP-11-31. Available at SSRN: http://ssrn.com/abstract=1946788 or http://dx.doi.org/10.2139/ssrn.1946788

Rosenbaum, P. R. and Rubin, A. B. (1983): “ The central role of the propensity score in observational studies for causal effects", Biometrica, 1083(70,1): 41-55

Rosenbaum, P.R. (2002). Observational Studies. New York, NY: Springer.

Shane, S. (2009) "Why encouraging more people to become entrepreneurs is bad public policy”, Small Business Economics, 33: 141-149.

Sianesi, B. (2004) "An evaluation of the Swedish system of active labour market programmes in the 1990s", Review of Economics and Statistics 86(1): 133-155.

Sigeman, T. (1999): "Insiders and Outsiders in the Labour Market. Experiences of a Nordic Welfare State in Labour Law Perspective", Scandinavian Studies in Law.

Skans, N. O., Edin, P. A. and Holmlund, B. (2006): "Wage dispersion between and within plants: Sweden 1985-2000”, IFAU-Institute for labor market policy evaluation, Working paper 9 
Smith, J. (2000) A critical survey of empirical methods for evaluating active labor market policies. Schweizerische Zeitschrift fuer Volkswirtschaft und Statistik, 136(3): 1-22.

Smith, J. and Todd, P. (2005) 'Does matching overcome LaLonde's critique of nonexperimental estimators?", Journal of Econometrics, 125(1-2): 305-353.

Taubman, P (1989). "Role of Parental Income in Educational Attainment", The American Economic Review, 79(2): 57-61.

Troske, K. R. (1999) "Evidence on the employer size-wage premium from workerestablishment matched data", The review of Economics and Statistics, 81 (1): 15-26.

van Praag, M.C. and P.H. Versloot (2007) "What is the Value of Entrepreneurship? A Review of Recent Research", Small Business Economics, 29(4):351-382,

Waddoups, C. J. (2007) "Employer Size-wage Effects in Australia", Labour, 21 (4-5): 809-835.

Wagner, J. (1997) "Firm Size and Job Quality: A Survey of the Evidence from Germany", Small Business Economics, 9: 411-425.Wheaton, W. C. and Lewis, M.L. (2002): "Urban Wages and Labor Market Agglomeration", Journal of Urban Economics, 51: 542-562. 
Table 1 Wage distribution (in SEK)

Model I

(new firms)
Model II

(firms up to 3 years old)
Model III

(firms up to 5 years old)

\begin{tabular}{|c|c|c|c|c|c|c|c|c|}
\hline & Year & New firms & Incumbent & New firms & Incumbent & New firms & Incumbent & Total \\
\hline & Mean & 135318.4 & 142908.16 & 135114.01 & 143344.75 & 134945.61 & 143493.65 & 142227.2 \\
\hline \multirow[t]{3}{*}{1998} & St.Dev. & 45939.223 & 46250.171 & 42495.332 & 46740.551 & 41808.039 & 46890.984 & 46271.7 \\
\hline & $\mathrm{N}$ & 1348 & 13677 & 2040 & 12985 & 2226 & 12799 & 15025 \\
\hline & Mean & 142052.04 & 148414.47 & 142354.79 & 148688.68 & 142248.62 & 148814.25 & 147701.5 \\
\hline \multirow[t]{3}{*}{1999} & St.Dev. & 41264.653 & 49429.348 & 40290.693 & 49948.602 & 39712.289 & 50176.194 & 48622.84 \\
\hline & $\mathrm{N}$ & 1571 & 12448 & 2185 & 11834 & 2376 & 11643 & 14019 \\
\hline & Mean & 154232.03 & 157132.99 & 154937.09 & 157112.24 & 154360.38 & 157265.64 & 156729.8 \\
\hline \multirow[t]{3}{*}{2000} & St.Dev. & 55805.272 & 50226.605 & 58071.367 & 49412.865 & 57212.642 & 49532.424 & 51046.7 \\
\hline & $\mathrm{N}$ & 2596 & 16083 & 3284 & 15395 & 3445 & 15234 & 18679 \\
\hline & Mean & 157917.73 & 169546.15 & 160016.57 & 169799.84 & 160411.35 & 169860.97 & 168151.9 \\
\hline \multirow[t]{3}{*}{2001} & St.Dev. & 52768.45 & 65951.466 & 53286.124 & 66564.947 & 53540.593 & 66702.586 & 64621.85 \\
\hline & $\mathrm{N}$ & 1603 & 11766 & 2252 & 11117 & 2418 & 10951 & 13369 \\
\hline & Mean & 158223 & 163745.17 & 159894.68 & 163836.02 & 159150.63 & 164045.05 & 163227.9 \\
\hline \multirow[t]{3}{*}{2002} & St.Dev. & 60126.441 & 51827.505 & 60697.678 & 51064.325 & 59113.251 & 51260.7 & 52681.97 \\
\hline & $\mathrm{N}$ & 1043 & 10092 & 1718 & 9417 & 1859 & 9276 & 11135 \\
\hline & Mean & 164161.76 & 170569.68 & 163470.77 & 171224.17 & 163626.47 & 171335.98 & 169933.5 \\
\hline \multirow[t]{3}{*}{2003} & St.Dev. & 63473.075 & 55337.977 & 56262.998 & 56134.703 & 56991.391 & 55963.2 & 56227.5 \\
\hline & $\mathrm{N}$ & 996 & 9036 & 1670 & 8362 & 1825 & 8207 & 10032 \\
\hline & Mean & 168355.23 & 172733.11 & 167853.27 & 173129.65 & 168111.48 & 173198.47 & 172330.8 \\
\hline \multirow[t]{3}{*}{2004} & St.Dev. & 56792.606 & 55477.495 & 56316.796 & 55449.655 & 55771.87 & 55541.678 & 55611.26 \\
\hline & $\mathrm{N}$ & 959 & 9477 & 1580 & 8856 & 1780 & 8656 & 10436 \\
\hline & Mean & 175670.17 & 180755.09 & 174883.65 & 181158.71 & 175091.16 & 181302.38 & 180183.3 \\
\hline \multirow[t]{3}{*}{2005} & St.Dev. & 54315.285 & 59184.39 & 55142.91 & 59255.365 & 55259.392 & 59345.762 & 58676.85 \\
\hline & $\mathrm{N}$ & 1305 & 10301 & 1804 & 9802 & 2091 & 9515 & 11606 \\
\hline & Mean & 174979.71 & 184021.78 & 175719.79 & 184308.05 & 176297.35 & 184348.8 & 182829.2 \\
\hline \multirow[t]{3}{*}{2006} & St.Dev. & 52545.097 & 60236.464 & 51759.173 & 60715.072 & 53959.731 & 60444.01 & 59356.57 \\
\hline & $\mathrm{N}$ & 2065 & 13592 & 2696 & 12961 & 2955 & 12702 & 15657 \\
\hline & Mean & 181989.65 & 193226.18 & 183552.91 & 193488.3 & 183555.59 & 193637.68 & 191658 \\
\hline \multirow[t]{3}{*}{2007} & St.Dev. & 46300.572 & 79250.552 & 55929.13 & 79279.985 & 55385.423 & 79663.556 & 75619.36 \\
\hline & $\mathrm{N}$ & 2300 & 14180 & 3036 & 13444 & 3236 & 13244 & 16480 \\
\hline & Mean & 194525.99 & 206395.77 & 194703.73 & 207066.13 & 194555.51 & 207273.23 & 204766.6 \\
\hline \multirow[t]{2}{*}{2008} & St.Dev. & 55752.901 & 72288.294 & 55058.115 & 73226.236 & 54640.058 & 73501.462 & 70366.62 \\
\hline & $\mathrm{N}$ & 1993 & 12528 & 2701 & 11820 & 2862 & 11659 & 14521 \\
\hline
\end{tabular}

Note: We use three definitions of new firms: firms established less than one year ago (Model I), firms that are up to three years old (Model II), and firms that are up to five years old (Model III). Incumbent firms in each model are firms not defined as new firms. 
Table 2 Descriptive statistics (2008)

\begin{tabular}{|c|c|c|c|c|c|c|c|c|c|}
\hline \multirow[b]{2}{*}{ Variables } & \multicolumn{3}{|c|}{$\begin{array}{c}\text { Model I } \\
\text { (new firms) }\end{array}$} & \multicolumn{3}{|c|}{$\begin{array}{c}\text { Model II } \\
\text { (firms up to } 3 \text { years old) }\end{array}$} & \multicolumn{3}{|c|}{$\begin{array}{c}\text { Model III } \\
\text { (firms up to } 5 \text { years old) }\end{array}$} \\
\hline & New firms & Incumbent & T-test & New firms & Incumbent & T-test & New firms & Incumbent & T-test \\
\hline & Mean & Mean & p-value & Mean & Mean & p-value & Mean & Mean & p-value \\
\hline Age & 23.406 & 23.455 & 0.550 & 23.558 & 23.423 & 0.063 & 23.530 & 23.428 & 0.155 \\
\hline Age squared & 558.918 & 561.869 & 0.457 & 566.482 & 560.317 & 0.079 & 565.123 & 560.566 & 0.184 \\
\hline Gender $(d)$ & 0.297 & 0.288 & 0.412 & 0.296 & 0.288 & 0.408 & 0.297 & 0.287 & 0.290 \\
\hline Immigrant $(d)$ & 0.490 & 0.431 & 0.000 & 0.491 & 0.427 & 0.000 & 0.487 & 0.427 & 0.000 \\
\hline Europe and North America $(d)$ & 0.213 & 0.220 & 0.535 & 0.227 & 0.217 & 0.240 & 0.226 & 0.217 & 0.276 \\
\hline Non-Europe/North America (d) & 0.218 & 0.167 & 0.000 & 0.205 & 0.167 & 0.000 & 0.203 & 0.167 & 0.000 \\
\hline Secondary education $(d)$ & 0.621 & 0.577 & 0.000 & 0.607 & 0.578 & 0.008 & 0.607 & 0.578 & 0.007 \\
\hline Tertiary education $(d)$ & 0.217 & 0.281 & 0.000 & 0.227 & 0.282 & 0.000 & 0.227 & 0.283 & 0.000 \\
\hline$G P A$ & 10.977 & 11.894 & 0.000 & 11.074 & 11.919 & 0.000 & 11.036 & 11.938 & 0.000 \\
\hline Father's secondary education $(d)$ & 0.590 & 0.618 & 0.053 & 0.591 & 0.620 & 0.026 & 0.593 & 0.619 & 0.041 \\
\hline Father's tertiary education $(d)$ & 0.197 & 0.162 & 0.002 & 0.184 & 0.163 & 0.032 & 0.183 & 0.163 & 0.040 \\
\hline Mother's secondary education (d) & 0.628 & 0.639 & 0.435 & 0.634 & 0.638 & 0.723 & 0.630 & 0.639 & 0.476 \\
\hline Mother's tertiary education $(d)$ & 0.192 & 0.196 & 0.707 & 0.190 & 0.197 & 0.493 & 0.190 & 0.197 & 0.499 \\
\hline Stockholm $(d)$ & 0.387 & 0.346 & 0.000 & 0.387 & 0.344 & 0.000 & 0.383 & 0.344 & 0.000 \\
\hline Gothenburg $(d)$ & 0.101 & 0.112 & 0.152 & 0.104 & 0.112 & 0.258 & 0.107 & 0.111 & 0.578 \\
\hline $\operatorname{Malmo}(d)$ & 0.144 & 0.128 & 0.050 & 0.146 & 0.127 & 0.006 & 0.142 & 0.127 & 0.035 \\
\hline Pedagogical and arts $(d)$ & 0.093 & 0.090 & 0.593 & 0.094 & 0.089 & 0.434 & 0.094 & 0.089 & 0.423 \\
\hline Social $(d)$ & 0.097 & 0.091 & 0.376 & 0.099 & 0.090 & 0.143 & 0.097 & 0.090 & 0.276 \\
\hline Technical $(d)$ & 0.238 & 0.316 & 0.000 & 0.240 & 0.320 & 0.000 & 0.240 & 0.321 & 0.000 \\
\hline \# of observations & 1993 & 12528 & & 2701 & 11820 & & 2862 & 11659 & \\
\hline
\end{tabular}

Note: t-test is used for differences in means. Dummy variables are indicated by $(d)$. 
Table 3. Binary logit estimation results for selection into new firms (2008)

\begin{tabular}{|c|c|c|c|c|c|c|c|c|c|}
\hline \multirow[t]{2}{*}{ Variables } & \multicolumn{3}{|c|}{$\begin{array}{c}\text { Model I } \\
\text { (new firms) }\end{array}$} & \multicolumn{3}{|c|}{$\begin{array}{c}\text { Model II } \\
\text { (firms up to } 3 \text { years old) }\end{array}$} & \multicolumn{3}{|c|}{$\begin{array}{c}\text { Model III } \\
\text { (firms up to } 5 \text { years old) }\end{array}$} \\
\hline & Coeff. & Std. & $\partial \mathrm{y} / \partial \mathrm{x}$ & Coeff. & Std. Err. & $\partial y / \partial x$ & Coeff. & Std. & $\partial y / \partial x$ \\
\hline Age & $0.469^{* *}$ & 0.225 & 0.050 & 0.268 & 0.192 & 0.037 & 0.283 & 0.189 & 0.041 \\
\hline Age squared & $-0.011^{* *}$ & 0.005 & -0.001 & -0.006 & 0.004 & -0.001 & -0.006 & 0.004 & -0.001 \\
\hline Gender $(d)$ & $0.131^{*}$ & 0.079 & 0.014 & 0.111 & 0.070 & 0.016 & $0.119^{*}$ & 0.069 & 0.017 \\
\hline Immigrant $(d)$ & $0.336^{* *}$ & 0.131 & 0.040 & $0.437^{* * *}$ & 0.116 & 0.067 & $0.377^{* * *}$ & 0.115 & 0.059 \\
\hline Europe and North America $(d)$ & -0.119 & 0.207 & -0.012 & $-0.355^{*}$ & 0.190 & -0.044 & -0.306 & 0.187 & -0.040 \\
\hline Non-Europe/North America (d) & 0.217 & 0.190 & 0.025 & -0.130 & 0.177 & -0.017 & -0.081 & 0.174 & -0.011 \\
\hline Secondary education $(d)$ & 0.180 & 0.237 & 0.019 & 0.034 & 0.209 & 0.005 & 0.104 & 0.206 & 0.015 \\
\hline Tertiary education $(d)$ & -0.190 & 0.281 & -0.020 & -0.225 & 0.248 & -0.030 & -0.132 & 0.244 & -0.019 \\
\hline$G P A$ & $-0.022^{* * *}$ & 0.007 & -0.002 & $-0.021^{* * *}$ & 0.006 & -0.003 & $-0.0241^{* * *}$ & 0.006 & -0.003 \\
\hline Father's secondary education (d) & -0.009 & 0.091 & -0.001 & -0.031 & 0.080 & -0.004 & -0.010 & 0.078 & -0.001 \\
\hline Father's tertiary education (d) & $0.312^{* * *}$ & 0.120 & 0.036 & 0.147 & 0.108 & 0.021 & $0.178^{*}$ & 0.105 & 0.027 \\
\hline Mother's secondary education (d) & -0.008 & 0.103 & -0.001 & 0.043 & 0.093 & 0.006 & 0.005 & 0.091 & 0.001 \\
\hline Mother's tertiary education ( $d$ ) & -0.077 & 0.130 & -0.008 & -0.030 & 0.117 & -0.004 & -0.059 & 0.114 & -0.008 \\
\hline Stockholm $(d)$ & 0.107 & 0.083 & 0.012 & $0.154^{* *}$ & 0.074 & 0.022 & $0.139^{*}$ & 0.072 & 0.020 \\
\hline Gothenburg (d) & 0.142 & 0.114 & 0.016 & 0.165 & 0.102 & 0.024 & $0.188^{*}$ & 0.098 & 0.028 \\
\hline Malmo $(d)$ & 0.122 & 0.109 & 0.014 & $0.167^{*}$ & 0.098 & 0.024 & 0.098 & 0.097 & 0.014 \\
\hline Pedagogical and arts $(d)$ & 0.034 & 0.108 & 0.004 & 0.045 & 0.097 & 0.006 & 0.023 & 0.095 & 0.003 \\
\hline Social $(d)$ & 0.123 & 0.130 & 0.014 & 0.118 & 0.116 & 0.017 & 0.079 & 0.114 & 0.012 \\
\hline Technical (d) & $-0.297^{* * *}$ & 0.091 & -0.031 & $-0.283^{* * *}$ & 0.080 & -0.038 & $-0.286^{* * *}$ & 0.078 & -0.040 \\
\hline Constant & $-7.259^{* * *}$ & 2.606 & & $-4.604^{* *}$ & 2.234 & & $-4.661^{* *}$ & 2.199 & \\
\hline \# of observations & 7855 & & & 7855 & & & 7855 & & \\
\hline Pseudo $R^{2}$ & 0.019 & & & 0.015 & & & 0.015 & & \\
\hline
\end{tabular}

Note: Dummy variables are indicated by $(d) ;{ }^{*} p<0.10,{ }^{* *} p<0.05,{ }^{* * *} p<0.01 ; \partial \mathrm{y} / \partial \mathrm{x}$ is for discrete change of dummy variable from 0 to 1 , the marginal effect evaluated at the mean, the change in probability if the dummy changes from 0 to 1 .

Table 4 Effects of treatment on wages (2008)

\begin{tabular}{lccccccccc}
\hline & & \multicolumn{3}{c}{$\begin{array}{c}\text { Model I } \\
\text { (new firms) }\end{array}$} & \multicolumn{3}{c}{$\begin{array}{c}\text { Model II } \\
\text { (up to 3 years old firms) }\end{array}$} & \multicolumn{3}{c}{$\begin{array}{c}\text { Model III } \\
\text { (up to 5 years old firms) }\end{array}$} \\
\hline \multicolumn{1}{c}{ Method } & ATT & Effect & $\begin{array}{c}\text { Bootstrap } \\
\text { errors }\end{array}$ & ATT & Effect & $\begin{array}{c}\text { Bootstrap } \\
\text { errors }\end{array}$ & $\begin{array}{c}\text { ATT } \\
\text { Effect }\end{array} \begin{array}{c}\text { Bootstrap } \\
\text { errors }\end{array}$ \\
\hline NNM without replacement & 12.112 & -0.039 & $0.009^{* * *}$ & 12.117 & -0.030 & $0.009^{* * *}$ & 12.116 & -0.039 & $0.009^{* * *}$ \\
NNM with replacement & 12.112 & -0.041 & $0.013^{* * *}$ & 12.117 & -0.029 & $0.009^{* * *}$ & 12.116 & -0.039 & $0.010^{* * *}$ \\
NNM with 2 neighbors & 12.112 & -0.036 & $0.010^{* * *}$ & 12.117 & -0.034 & $0.009^{* * *}$ & 12.116 & -0.038 & $0.008^{* * *}$ \\
NNM with caliper (0.001) & 12.112 & -0.035 & $0.010^{* * *}$ & 12.117 & -0.031 & $0.008^{* * *}$ & 12.116 & -0.041 & $0.008^{* * *}$ \\
NNM with caliper (0.01) & 12.112 & -0.034 & $0.010^{* * *}$ & 12.117 & -0.031 & $0.009^{* * *}$ & 12.116 & -0.040 & $0.009^{* * *}$ \\
NNM with caliper (0.02) & 12.112 & -0.036 & $0.010^{* * *}$ & 12.117 & -0.027 & $0.010^{* * *}$ & 12.116 & -0.038 & $0.009^{* * *}$ \\
\hline
\end{tabular}

Note: NNM, nearest neighbor matching. Log of wages is used; bootstrapping test, 100 replications. ${ }^{*} p<0.10,{ }^{* * *} p<0.05,{ }^{* * * *} p<0.01$ 
Table 5 Effects of treatment on wages

\begin{tabular}{|c|c|c|c|c|c|c|c|c|c|}
\hline \multirow[b]{2}{*}{ Year } & \multicolumn{3}{|c|}{$\begin{array}{c}\text { Model I } \\
\text { (new firms) }\end{array}$} & \multicolumn{3}{|c|}{$\begin{array}{c}\text { Model II } \\
\text { (up to } 3 \text { years old firms) } \\
\end{array}$} & \multicolumn{3}{|c|}{$\begin{array}{c}\text { Model III } \\
\text { (up to } 5 \text { years old firms) }\end{array}$} \\
\hline & ATT & Effect & $\begin{array}{l}\text { Bootstrap } \\
\text { errors }\end{array}$ & ATT & Effect & $\begin{array}{l}\text { Bootstrap } \\
\text { errors }\end{array}$ & ATT & Effect & $\begin{array}{l}\text { Bootstrap } \\
\text { errors }\end{array}$ \\
\hline 1998 & 11.771 & -0.026 & $0.011^{* *}$ & 11.773 & -0.043 & $0.011 * * *$ & 11.772 & -0.035 & $0.009 * * *$ \\
\hline 1999 & 11.827 & -0.030 & $0.011^{* * *}$ & 11.837 & -0.006 & 0.011 & 11.835 & -0.006 & 0.010 \\
\hline 2000 & 11.894 & -0.022 & $0.008^{* * * *}$ & 11.898 & -0.026 & $0.009 * * *$ & 11.895 & -0.029 & $0.009 * * *$ \\
\hline 2001 & 11.929 & -0.017 & 0.013 & 11.944 & -0.017 & 0.011 & 11.945 & -0.007 & 0.011 \\
\hline 2002 & 11.924 & -0.022 & $0.013 *$ & 11.932 & -0.021 & $0.012 * *$ & 11.928 & -0.028 & $0.013^{* *}$ \\
\hline 2003 & 11.961 & -0.041 & $0.019^{* *}$ & 11.964 & -0.036 & $0.014 * *$ & 11.962 & -0.031 & $0.014 * *$ \\
\hline 2004 & 11.974 & -0.026 & $0.016^{*}$ & 11.976 & -0.038 & $0.014 * * *$ & 11.977 & -0.049 & $0.013 * * *$ \\
\hline 2005 & 12.015 & -0.041 & $0.013^{* * *}$ & 12.017 & -0.041 & $0.010 * * *$ & 12.017 & -0.035 & $0.012 * * *$ \\
\hline 2006 & 12.040 & -0.027 & $0.010 * * *$ & 12.041 & -0.029 & $0.010 * * *$ & 12.043 & -0.024 & $0.010^{* *}$ \\
\hline 2007 & 12.075 & -0.034 & $0.011^{* * *} *$ & 12.076 & -0.036 & $0.009 * * *$ & 12.076 & -0.035 & $0.008^{* * *}$ \\
\hline 2008 & 12.112 & -0.039 & $0.009 * * *$ & 12.117 & -0.030 & $0.009 * * *$ & 12.116 & -0.039 & $0.009 * * *$ \\
\hline Average & 11.957 & -0.029 & & 11.961 & -0.029 & & 11.961 & -0.029 & \\
\hline
\end{tabular}

